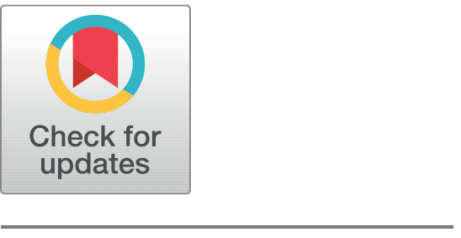

G OPEN ACCESS

Received: 12.04.2021

Accepted: 06.05.2021

Published: 22.05 .2021

Citation: Thirupathi $\mathrm{P}$, Venkatraman BR (2021) Corrosion inhibition behaviour on carbon steel in well-water by Ethanolic extract of Portulaca quadrifida (Chicken weed) leaves. Indian Journal of Science and Technology 14(18): 1488-1504. https://doi.org/ 10.17485/IJST/v14i18.630

* Corresponding author.

Tel: +919750435441

chemthiru@yahoo.in

Funding: None

Competing Interests: None

Copyright: @ 2021 Thirupathi \& Venkatraman. This is an open access article distributed under the terms of the Creative Commons Attribution License, which permits unrestricted use, distribution, and reproduction in any medium, provided the original author and source are credited.

Published By Indian Society for Education and Environment (iSee)

ISSN

Print: 0974-6846

Electronic: 0974-5645

\section{Corrosion inhibition behaviour on carbon steel in well-water by Ethanolic extract of Portulaca quadrifida (Chicken weed) leaves}

\author{
P Thirupathi ${ }^{\text {* }}$, B R Venkatraman ${ }^{1}$ \\ 1 PG \& Research Department of Chemistry, Periyar E.V.R. College (Autonomous), Affiliated to \\ Bharathidasan University, Tiruchirappalli, 620 023, Tamilnadu, India. Tel.: +91975 0435441
}

\section{Abstract}

Objectives: To evaluate the corrosion inhibition of an ethanolic extract of Portulaca quadrifida (PQ) leaves on the carbon steel surface in well-water by using a weight-loss study with various immersion periods, temperatures, and $\mathrm{pH}$. The kinetic and thermodynamic parameters are calculated for various temperatures. Methods: The protective film has been analyzed by using SEM, EDX and AFM studies. The inhibition action of PQ extract was analyzed by potentiodynamic polarization study, the electrochemical impedance studies are used to the analysis the protective layer formed on the carbon steel surface. Findings: The maximum inhibition efficiency is found to be $92 \%$ for $500 p p m$ of $\mathrm{PQ}$ and $30 \mathrm{ppm}$ of $\mathrm{Zn}^{2+}$ ions at 303K. The synergistic effect exists between ethanolic extract of Portulaca quadrifida leaves and $\mathrm{Zn}^{2+}$ ions by synergistic parameters. The ethanolic extract of $P Q$ leaves acts as a mixed-type inhibitor. The activation energy $\left(\mathrm{E}_{a}\right)$ values indicate that the adsorption of $P Q$ leaves extract on the carbon steel surface. The enthalpy of adsorption $(\Delta \mathrm{H})$ values suggests that the reaction is endothermic. The free energy of adsorption $\left(\Delta \mathrm{G}_{a d s}\right)$ values is negative and less than the $-20 \mathrm{KJmol}^{-1}$. The negative values of $\Delta \mathrm{S}_{a d s}$ are confirmed to form an ordered stable layer of the inhibitor molecule on the carbon steel surface as well as a stable equilibrium between the adsorption and desorption processes. The adsorption isotherm is best fitted with the Langmuir model. Novelty: The $\Delta \mathrm{G}_{\text {ads }}$ values indicate that the adsorption of inhibitor on the carbon steel surface belongs to the physisorption as well as the adsorption layer has an electrostatic character. The adsorption process of the inhibitor is spontaneous. The thermodynamic parameters give a strong interaction between the inhibitor molecules and carbon steel surface. Four adsorption isotherms including Langmuir, El-Awady, Flory-Huggins, and Temkin models, investigate the mode of inhibition of $\mathrm{PQ}$ leaves extract.

Keywords: Carbon steel corrosion; weightloss study; electrochemical studies; Ftest; synergistic effect; SEM; EDX; AFM; adsorption isotherms 


\section{Introduction}

Corrosion is a natural process in which an unstable metal is transformed into a chemically stable form, such as oxide and hydroxide forms by the mineral chemically or the electrochemical with the surrounding environment ${ }^{(1)}$. Corrosion is an undesirable phenomenon as it destroys the beneficial properties of the mineral ${ }^{(2)}$. Because of corrosion many useful properties of metal like malleability, ductility, and electrical conductivity is lost. Synthetic organic compounds are widely used as corrosion inhibitors for the prevention of corrosion of the many metals and alloys in various aggressive environments. Due to their hazardous nature, researchers focus their attention on developing cheap, non-toxic, biodegradable, and environment-friendly natural products of plant origin as corrosion inhibitors ${ }^{(3-12)}$. The inhibition proficiency of synthesized or natural organic compounds principally depends on the structure and trait of the adsorbed layer on the low-carbon steel ${ }^{(13-24)}$. Availableness of the unshared or $\pi$-electrons in inhibitor structure encourages the exchange from the inhibitor to the low-carbon steel due to the vacant $d$-orbital for the transition elements and therefore the formation of the coordination bond. Coordination bonds, including the exchange of electrons between inhibitor-molecules and therefore the surface of the metal, might occur. Traditional corrosion inhibitors contain chemical compounds that can have toxicological effects and pose harmful impacts on the receiving environment, especially surface waters ${ }^{(25)}$. Therefore, eco-friendly corrosion inhibitors also known popularly as green alternatives to replace toxic and hazardous chemicals are studied extensively in recent years ${ }^{(26-28)}$. Among all the green alternatives, the utilization of corrosion inhibitors obtained from plant extracts has continued to draw in interest thanks to their low human and environmental toxicity. Compared to synthetic inhibitors, plant extract-based corrosion inhibitors also cost less, and may easily be mass-produced if necessary ${ }^{(29)}$. The plant extract-based additives are used for rust mitigation in armors even during the medieval period ${ }^{(30,31)}$.

\section{Experimental methods}

\subsection{Composition and preparation of specimen}

The percentages of composition for carbon steel specimen are P 0.06\%, Mn 0.4\%, S 0.0267\%, C 0.1\% and Iron 99.287\%. The carbon steel sheet is cut into $1.5 \mathrm{~cm} \times 3.5 \mathrm{~cm} \times 0.2 \mathrm{~cm}$ for weightless measurement. The carbon steel was polished using Allen paper $1 / 0,2 / 0,3 / 0,4 / 0,5 / 0$, and $6 / 0$. The impurities using double distilled water and acetone, dried and kept in a desiccator then weighing accurately by a digital balance [Shimadzu Ay 62]

\subsection{Preparation of the Portulaca quadrifida Extract}

By refluxing $10 \mathrm{~g}$ of dried Portulaca quadrifida tends to leave in presence of $200 \mathrm{ml}$ of ethanol for $3 \mathrm{~h}$, the plant extract is prepared and then filtered off using whatmann filter paper. By using distilled water, these crude extracts were dried and then a dense solid mass was obtained. $1 \mathrm{~g}$ of Pisonia alba crushed up leaves has been decided to make with a 100 $\mathrm{ml}$ Standard Measuring Flask with double distilled water up to the mark. Various amounts of leaves extracts are decided to make from this solution. The major active compound obtained from an ethanolic extract of PQ leaves is shown in Figure 1.

\section{Beta Caryophyllene Oxide}

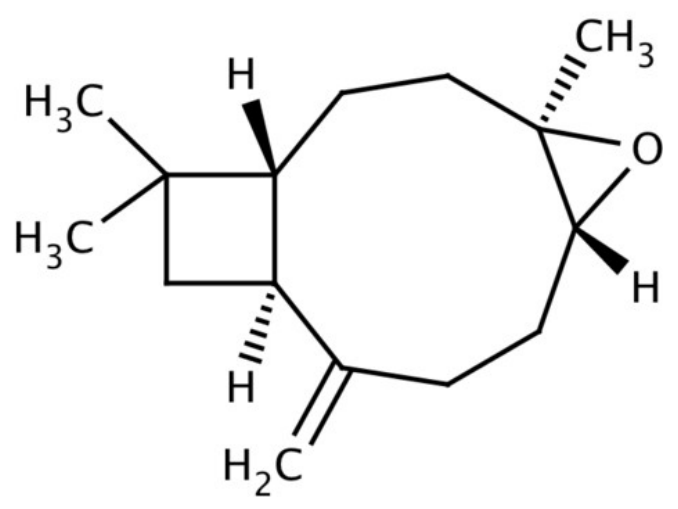

Fig 1. Major active component observed in ethanolic extract of Portulaca quadrifida leaves 


\subsection{Weight loss study}

The carbon steel specimens are immersed in well water with and without various inhibitor concentrations. After the immersion the carbon steel is removed from various test solution, thoroughly washed with double distilled water, dried well and weighted accurately again. From the average weight-loss, the inhibition efficiency ${ }^{(32)}$ and corrosion rate ${ }^{(33-35)}$ are calculated using the following equations.

$$
\begin{gathered}
I E \%=\frac{W_{\text {BLANK }}-W_{\text {INHIBITOR }}}{W_{\text {BLANK }}} \times 100 \\
\text { Corrosion Rate }(\text { mmpy })=\frac{87.6 \times \text { Weight loss }(\mathrm{mg})}{D \times A \times T}
\end{gathered}
$$

\subsection{Electrochemical studies}

Polarization and electrochemical impedance studies are carried out using $\mathrm{CHI}$ electrochemical impedance analyzer (model 760D) a universal programmer in a conventional three-electrode glass cell. The working electrode is a rectangular specimen of carbon steel with one face of the electrode $\left(\mathrm{km}^{2}\right.$ area) exposed and the rest shielded with red lacquer, a rectangular platinum foil act as a counter electrode and a saturated calomel electrode (SCE) is used to the reference electrode. From the polarization curves, corrosion potential $\left(\mathrm{E}_{\text {corr }}\right)$, corrosion current $\left(\mathrm{I}_{\text {corr }}\right)$ and Tafel slopes values are calculated. A time interval of 10 to 15 minutes is given for the system to attain a steady-state open-circuit potential. From the AC-impedance study, the double layer capacitance and charge transfer resistance values are calculated using An AC frequency range from $0.1 \mathrm{~Hz}$ to $100 \mathrm{kHz}$.

The inhibition efficiency is calculated using the following equations ${ }^{(36)}$

From polarization study,

$$
I E \%=\frac{I_{\text {corrosion(blank) }}-I_{\text {corrosion }(\text { inhibitor })}}{I_{\text {corrosion }(\text { blank })}} \times 100
$$

From AC impedance study,

$$
I E \%=\frac{R_{c t(\text { inhibitor })}-R_{c t(\text { blank })}}{R_{c t(\text { inhibitor })}} \times 100
$$

\subsection{SEM analysis}

The surface morphology analysis for the polished, corroded area and protective layer on carbon steel surface was examined by JEOLMODEL 6390 SEM.

\subsection{Synergistic effect}

The carbon steel immersed in well water contains various concentration of PQ with $\mathrm{Zn}^{2+}$ ions. The synergism parameters are used to determine the synergistic effect existing between plant extract and $\mathrm{Zn}^{2+}$ ions

The synergism parameters are calculated using the following formula ${ }^{(37)}$

$$
\begin{gathered}
S_{I}=\frac{1-\theta_{1+2}}{1-\theta^{\prime}{ }_{1+2}} \\
\theta_{1+2}=\left(\theta_{1}+\theta_{2}\right)-\left(\theta_{1} \times \theta_{2}\right)
\end{gathered}
$$

Where, $\mathrm{q}_{1}$ and $\mathrm{q}_{2}$ are surface coverage, $\mathrm{q}_{1+2}^{\prime}$ is cumulative surface coverage

\subsection{F-study}

F-analysis is used to determine the inhibitor system statistically significant or not through synergistic effect between plant extract and $\mathrm{Zn}^{2+}$ ions 


\subsection{AFM Technique}

Atomic force microscope study was utilized to surface morphology on the carbon steel in well water contains various concentration of PQ with $\mathrm{Zn}^{2+}$ ions using the Veeco dinnova model with a scan rate of $0.6 \mathrm{~Hz} / \mathrm{second}$

\section{Result and Discussions}

\subsection{Weight-loss Measurement}

The corrosion inhibition effects of an ethanolic extract of Portulaca quadrifida over carbon steel immersed in well water contain $\mathrm{Zn}^{2+}$ ions are studied. The weight-loss study was utilized to calculate the inhibition efficiency and corrosion rate for carbon steel immersed in well water containing various concentrations of PQ $\mathrm{Zn}^{2+}$ system for one day immersion period. The results are given in Table 1. The various concentrations of $\mathrm{PQ}$ with and without $\mathrm{Zn}^{2+}$ ions are plotted in Figure 2 .

Table 1. Determination of IE and CR of PQ- $\mathrm{Zn}^{2+}$ system (Period of immersion:1 day)

\begin{tabular}{lllllllll}
\hline & \multicolumn{3}{c}{$\mathrm{I.E} \%$} & \multicolumn{3}{c}{$\mathrm{CR}(\mathrm{mmpy})$} \\
\cline { 2 - 9 } $\mathrm{PQ}(\mathrm{ppm})$ & \multicolumn{3}{c}{$\mathrm{Zn}^{2+}(\mathrm{ppm})$} & & \multicolumn{3}{c}{$\mathrm{Zn}^{2+}(\mathrm{ppm})$} \\
\cline { 2 - 9 } & 0 & 10 & 20 & 30 & 0 & 10 & 20 & 0.1339 \\
\hline 0 & - & 13 & 26 & 31 & 0.1809 & 0.1574 & 0.1249 \\
100 & 27 & 32 & 44 & 51 & 0.1320 & 0.1230 & 0.1013 & 0.0886 \\
200 & 36 & 44 & 56 & 62 & 0.1158 & 0.1013 & 0.0796 & 0.0687 \\
300 & 48 & 59 & 63 & 74 & 0.0941 & 0.0742 & 0.6693 & 0.0470 \\
400 & 55 & 67 & 73 & 86 & 0.0814 & 0.0597 & 0.0488 & 0.0253 \\
500 & 61 & 72 & 81 & 92 & 0.0706 & 0.0507 & 0.0344 & 0.0145 \\
\hline
\end{tabular}

The inhibition efficiency increased from $27 \%$ to $61 \%$ for various concentration of PQ in absence of $\mathrm{Zn}^{2+}$ ions. The combination of various concentration of $\mathrm{PQ}$ and $10 \mathrm{ppm} \mathrm{Zn}^{2+}$ gives the inhibition efficiency from $13 \%$ to $72 \%$ and also corrosion rate from 0.1574 to 0.0507 . The concentration of PQ and $20 \mathrm{ppm}$ of $\mathrm{Zn}^{2+}$ system gives the inhibition efficiency from $26 \%$ to $81 \%$ as well as corrosion rate 0.1339 to 0.0344 . The formulation of various concentration of $500 \mathrm{ppm}$ PQ and $30 \mathrm{ppm}^{\mathrm{p}} \mathrm{Z \textrm {n } ^ { 2 + }}$ system gives the optimum inhibition efficiency from $31 \%$ to $92 \%$ and also corrosion rate decreased from 0.1249 to 0.0145 . Therefore, it is evident that the inhibition efficiency increases with its concentration, which is due to the adsorption of the metallic complex on the carbon steel surface ${ }^{(38)}$. The fact that the metal surface area covered by the inhibitor surface coverage increases with its concentration supports the idea that the decrease in corrosion rate is due to the inhibitor adsorption on the carbon steel surface to form a protective corrosion product layer due to the existence of hetero cyclic compound is shown in Figure $1^{(39)}$. The mixture of inhibitors $\left(\mathrm{PQ}-\mathrm{Zn}^{2+}\right)$ has better IE than individual inhibitors ${ }^{(40-42)}$.

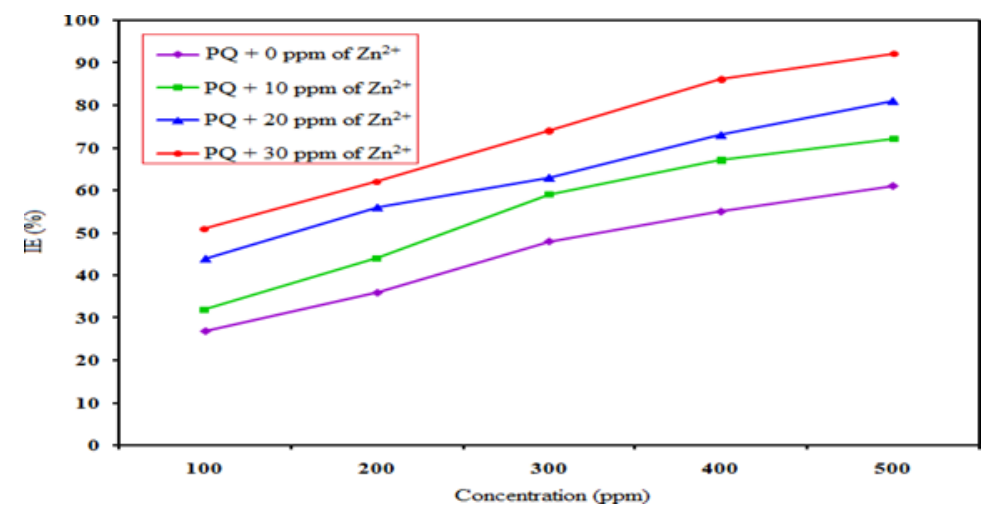

Fig 2. Influence of Immersion Period on the IE and CR for PQ- $\mathrm{Zn}^{2+}$ System

The above graph indicated that the IE\% increases, when the concentration of PQ and $\mathrm{Zn}^{2+}$ ions are increased from $100 \mathrm{ppm}$ to 500ppm (PQ) and (0ppm to 300ppm) 


\subsection{Thermodynamic parameters}

The free energy of adsorption $\left(\Delta \mathrm{G}_{a d s}\right)$, the heat of adsorption $\left(\mathrm{q}_{a d s}\right)$, and entropy of adsorption $\left(\Delta \mathrm{S}_{a d s}\right)$ values give the nature of adsorption on the metal surface. These values are shown in Table 2. The $\Delta \mathrm{G}_{a d s}, \mathrm{q}_{a d s}$ and $\Delta \mathrm{S}_{a d s}$ values are negative in sign. These negative values indicate that the adsorption of inhibitor systems has a spontaneous process with a high stability of the adsorbed film on the carbon steel surface due to physisorption ${ }^{(43,44)}$. These negative $\Delta \mathrm{G}_{a d s}$ values are less than $-20 \mathrm{kJmol}{ }^{-1}$, therefore, the nature of adsorption for PQ leaves is physisorption at all various temperatures. The negative values of $\Delta \mathrm{S}_{a d s}$ indicate that the adsorbed molecules (corrosion products) on the corrosion steel surface are ordered than in the solution (corrosion reactants) ${ }^{(1)}$. The thermodynamic corrosion parameters are calculated using following equations.

The free energy of adsorption was calculated using the following equation ${ }^{(45)}$.

$$
\triangle G_{a d s}=2.303 R T \log \left(55.5 K_{a d s}\right)
$$

Where, 55.5 is the molar concentration of water in solution and

$$
K_{a d s}=\frac{\theta}{C(1-\theta)}
$$

The heat of adsorption was calculated using the equation ${ }^{(33)}$

$$
q_{a d s}=2.303 R\left[\left(\frac{\theta_{T 2}}{1-\theta_{T 2}}\right)-\log \left(\frac{\theta_{T 1}}{1-\theta_{T 1}}\right)\left(\frac{T_{1} T_{2}}{T_{2}-T_{1}}\right)\right]
$$

$\theta_{T 1}$ is the surface coverage at lower temperature $\left(\mathrm{T}_{1}\right), \theta_{T 2}$ is the surface coverage at higher temperature $\left(\mathrm{T}_{2}\right)$

The entropy of adsorption $\left(\Delta \mathrm{S}_{a d s}\right)$ was calculated using the below relationship ${ }^{(1)}$

\begin{tabular}{|c|c|c|c|c|c|}
\hline Inhibitor system & Temperatures (K) & $\Delta \mathrm{G}_{a d s}(\mathrm{KJ} / \mathrm{mol})$ & $\mathrm{q}_{a d s}(\mathrm{KJ} / \mathrm{mol})$ & $\Delta \mathrm{S}_{a d s}(\mathrm{KJ} / \mathrm{mol})$ & $\mathrm{K}_{a d s}$ \\
\hline \multirow{4}{*}{ PQ } & 303 & -18.0 & -32.5 & -0.167 & 23.0 \\
\hline & 313 & -17.4 & -26.5 & -0.141 & 14.7 \\
\hline & 323 & -16.7 & -38.7 & -0.172 & 9.1 \\
\hline & 333 & -16.1 & -32.7 & -0.147 & 6.0 \\
\hline
\end{tabular}

$$
\triangle S_{a d s}=\frac{q_{a d s}-\triangle G_{a d s}}{T}
$$

Table 2. Effect of thermodynamic parameters on the adsorption process

\subsection{Kinetic parameters}

The $\mathrm{E}_{a}$ value is found to be $17.14 \mathrm{KJ} / \mathrm{mol}$ for the blank system. This value was increased by the presence of the inhibitor. Ea for PQ leaves extract is $101.0 \mathrm{KJ} / \mathrm{mol}$ at $500 \mathrm{ppm}$ systems. $\mathrm{E}_{a}$ values greater than $80 \mathrm{KJ} / \mathrm{mol}$ are consistent with chemisorption, while Ea values lower than $80 \mathrm{KJ} / \mathrm{mol}$ followed physisorption ${ }^{(32)}$. Therefore, Ea values indicate that the chemisorption on the carbon steel surface. The $\Delta \mathrm{H}$ value was increased from $14.6 \mathrm{KJ} / \mathrm{mol}$ to $98.5 \mathrm{KJ} / \mathrm{mol}$ for combined inhibitor (blank to $500 \mathrm{ppm}$ ) systems, The high positive $\Delta \mathrm{H}$ values of PQ leaves indicate that the reactions are endothermic ${ }^{(46)}$ for corrosion processes of carbon steel in well-water. The results are given in Table 3. The Kinetic parameters are calculated using following equations.

The activation energy $\left(\mathrm{E}_{a}\right)$ values are calculated using the following Arrhenius equation ${ }^{(32)}$

$$
E_{a}=2.303 R \log \left(\frac{C_{R T 1}}{C_{R T 2}}\right)\left[\frac{T_{1} T_{2}}{T_{2}-T_{1}}\right]
$$

$\mathrm{C}_{R T 1}$ is the corrosion rate of the lower temperature $\left(\mathrm{T}_{1}\right), \mathrm{C}_{R T 2}$ is the Corrosion rate at the higher temperature $\left(\mathrm{T}_{2}\right)$, and $\mathrm{R}$ is gas constant $(8.314 \mathrm{~J} / \mathrm{mol})$

The enthalpy change $(\Delta \mathrm{H})$ values are calculated using following equation ${ }^{(46)}$

$$
\triangle H=E_{a}-R T
$$


Table 3. Effect of kinetic parameters on the corrosion process

\begin{tabular}{lll}
\hline Concentration of combined inhibitor & Ea KJ/mol & $\Delta \mathrm{H} \mathrm{KJ} / \mathrm{mol}$ \\
\hline Blank & 17.1 & 14.6 \\
100 & 54.2 & 51.7 \\
200 & 57.8 & 55.2 \\
300 & 59.7 & 57.1 \\
400 & 72.2 & 69.6 \\
500 & 101.0 & 98.5 \\
\hline
\end{tabular}

\subsection{Effect of pH on PQ- Zn2+System:}

The effect of $\mathrm{pH}$ changes on PQ $\mathrm{Zn}^{2+}$ system in well water containing $500 \mathrm{ppm}$ of PQ and $30 \mathrm{ppm}$ of $\mathrm{Zn}^{2+}$. The inhibition efficiency and corrosion rate are calculated using weight loss measurement. The results are given in Table 4 .

Table 4. Influence of $\mathrm{pH}$ on IE and CR for PQ- $\mathrm{Zn}^{2+}$ inhibitor system (Period of Immersion: one day)

\begin{tabular}{llll}
\hline \multirow{2}{*}{ System } & \multicolumn{3}{c}{$\mathrm{pH}$} \\
\cline { 2 - 4 } & 3 & 8 & 0.1809 \\
Well-water CR (mmpy) & 0.2067 & 0.0145 & 0.1912 \\
PQ-Zn2+ system (500:30 ppm) & 0.0537 & & 0229 \\
CR (mmpy) & & 92 & 88 \\
IE (\%) & 74 & & \\
\hline
\end{tabular}

The maximum inhibition efficiency of $92 \%$ was obtained at $\mathrm{pH}$ of 8 for PQ- $\mathrm{Zn}^{2+}$ system. The inhibition efficiency was decreased from $92 \%$ to $74 \%$ when the $\mathrm{pH}$ is reduced from $\mathrm{pH} 8$ to 3 by the addition of dilute $\mathrm{HCl}$. The addition of $\mathrm{NaOH}$ to $\mathrm{PQ}-\mathrm{Zn}^{2+}$ system $(\mathrm{pH}=8)$, the $\mathrm{pH}$ is decreased from $92 \%$ to $88 \%$ as well as corrosion rate is increased ${ }^{(47,48)}$.

\subsection{Effect of Immersion Period on PQ- Zn2+System}

The effect of immersion period from 1to 7days on the corrosion inhibitor inhibition behaviour carbon steel in well-water contains a various concentration of $\mathrm{PQ}$ with $\mathrm{Zn}^{2+}$ ions, the inhibition efficiency and corrosion rate was calculated using weight study. The results are given in Table 5. The inhibition efficiency behaviour and immersion period are plotted in Figure 3.

Table 5. Effect of Immersion Period on PQ- $\mathrm{Zn}^{2+}$ System

\begin{tabular}{llll}
\hline \multirow{2}{*}{$\begin{array}{l}\text { Immersion Period } \\
\text { days })\end{array}$} & \multicolumn{3}{c}{ Corrosion Rate } \\
\cline { 2 - 4 } & Well-water (mmpy) & PQ- Zn2+ (500:30ppm)(mmpy) & 92 \\
\hline 1 & 0.1809 & 0.0145 & 88 \\
5 & 0.2013 & 0.0241 & 81 \\
7 & 0.2124 & 0.0404 & 70 \\
\hline
\end{tabular}

From the above result, the inhibition efficiency was decreased from $92 \%$ to $70 \%$ as well as corrosion rate increased from 0.1809 to 0.2158 in well-water and absence of PQ- $\mathrm{Zn}^{2+}$ system, from 0.0145 to 0.0647 in presences of PQ- $\mathrm{Zn}^{2+}$ system. Therefore, the effect of immersion period on an ethanolic extract of plant leaves confirmed that the protective layer formed on the metal surface deteriorates and dissolves in the solution by the corrosion environment and enhances the corrosion process $^{(49,50)}$. 


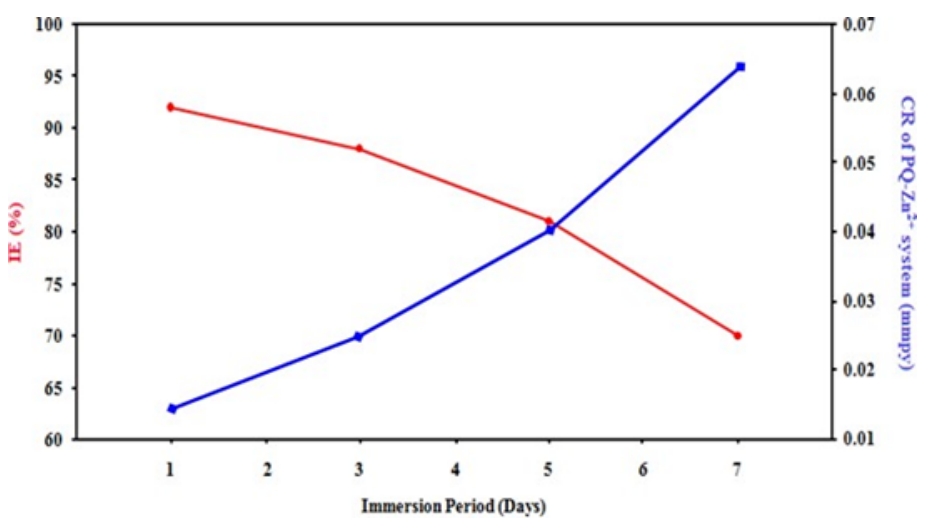

Fig 3. Influence of Immersion Period on the IE and CR for PQ- $\mathrm{Zn}^{2+}$ System

\subsection{Synergism Parameter}

The synergistic effect exists between the various concentration of PQ and $30 \mathrm{ppm}$ of $\mathrm{Zn}^{2+}$ ions. SI values approaches 1 when no interaction between the inhibitors. SI $<1$, synergistic effect exists between the two inhibitors ${ }^{(51-53)}$. Therefore, the synergistic inhibition effect was the improved performance of a mixture of inhibitors compared with the individual inhibitors ${ }^{(37)}$. The results are given in Table 6.

Table 6. Synergism Parameters for PQ- $\mathrm{Zn}^{2+}$ System

\begin{tabular}{lllllll}
\hline PQ $(\mathrm{ppm})$ & $\mathrm{Zn}^{2+}(30 \mathrm{ppm})$ & $\mathrm{q}_{1}$ & $\mathbf{q}_{2}$ & $\mathbf{q}_{1+2}^{\prime}$ & $\mathrm{S}_{\mathbf{I}}$ & IE \% \\
\hline 100 & 30 & 0.27 & 0.31 & 0.51 & 1.0280 & 51 \\
200 & 30 & 0.36 & 0.31 & 0.62 & 1.1621 & 62 \\
300 & 30 & 0.48 & 0.31 & 0.74 & 1.3800 & 74 \\
400 & 30 & 0.55 & 0.31 & 0.86 & 2.2179 & 86 \\
500 & 30 & 0.61 & 0.31 & 0.92 & 3.3638 & 92 \\
\hline
\end{tabular}

\subsection{F-Study}

F-Study was used to identification of the synergistic effect existing between the various concentration of PQ and $\mathrm{Zn}^{2+}$ has statistically significant or not ${ }^{(54-56)}$. The results are given in Table 7.

Table 7. F-value distributedbetween the IE of PQ- $\mathrm{Zn}^{2+}$ System

\begin{tabular}{|c|c|c|c|c|c|c|}
\hline $\mathrm{Zn}^{2+}(\mathrm{ppm})$ & Level of Significance of $\mathrm{F}$ & source of variance & sum of square & degree of freedom & mean square & F-values \\
\hline \multirow{2}{*}{10} & \multirow{2}{*}{$\mathrm{P}>0.05$} & Between & 220.9 & 1 & 220.9 & \multirow{2}{*}{0.95} \\
\hline & & Within & 1868 & 8 & 233.5 & \\
\hline \multirow{2}{*}{20} & \multirow{2}{*}{$\mathrm{P}>0.05$} & Between & 810 & 1 & 810 & \multirow{2}{*}{4.04} \\
\hline & & Within & 1602.4 & 8 & 200.3 & \\
\hline \multirow{2}{*}{30} & \multirow{2}{*}{$\mathrm{P}>0.05$} & Between & 1904.4 & 1 & 1904.4 & \multirow{2}{*}{8.11} \\
\hline & & Within & 1878.2 & 8 & 234.8 & \\
\hline
\end{tabular}

To examine where the effect of $\mathrm{Zn}^{2+}$ on the inhibition efficiencies of $\mathrm{PQ}$ is statistically significant F-study was carried out. The obtained F-value $0.95,4.04$ for $10 \mathrm{ppm} 20 \mathrm{ppm}$ of $\mathrm{Zn}^{2+}$ is not statistically significant. Hence it is less than the critical F-value 5.32 for 1.8 degree of freedom at 0.05 level of significance, therefore it is concluded that the effect of $10 \mathrm{ppm}, 20 \mathrm{ppm} \mathrm{of} \mathrm{Zn}^{2+}$ on the inhibition efficiencies of different concentration of PQ is not statistically significant ${ }^{(57)}$. The obtained F-value 8.11 for $30 \mathrm{ppm}$ of $\mathrm{Zn}^{2+}$ has statistically significant. Since, it is greater than the critical F-value 5.32 for 1.8 degree of freedom at 0.05 level of significance. Therefore, it is concluded that the effect of $30 \mathrm{ppm}$ of $\mathrm{Zn}^{2+}$ on the inhibition efficiencies of different concentrations of PQ is statistically significant ${ }^{(57)}$. 


\subsection{Analysis for Polarization Curves}

Polarization curves was used to calculate the corrosion parameters such as corrosion potential $\left(\mathrm{E}_{c o r r}\right)$, Tafel slopes, $\left(\mathrm{b}_{a}, \mathrm{~b}_{c}\right)$ linear polarization resistance and corrosion current Icorr values. The results are given in Table 8. When carbon steel is immersed in well-water, the corrosion potential is $-580 \mathrm{mV}$ vs SCE, the corrosion current is $5.5431 \mu \mathrm{A} / \mathrm{cm}^{2}$. When carbon steel is immersed in well-water containing 500ppm of PQ and $30 \mathrm{ppm}$ of $\mathrm{Zn}^{2+}$, the corrosion potential is shifted from -580 to $-603 \mathrm{mV}$ vs SCE. There is not much change in the corrosion potential value, it is concluded that the inhibitor system act as a mixed type of inhibitor, if the displacement in $\mathrm{E}_{\text {corr }}$ value is $>85 \mathrm{mV}$, the inhibitor can be seen as a cathodic or anodic type inhibitor; if the displacement of $\mathrm{E}_{\text {corr }}$ value is $<85 \mathrm{mV}$, the inhibitor can be seen as mixed type. In the present study the maximum displacement in $\mathrm{E}_{\text {corr }}$ was much lower than $85 \mathrm{mV}$ suggesting that PQ leaves extract is a mixed type with predominance of cathodic inhibition ${ }^{(58)}$. It is confirmed that the cathodic reaction is controlled predominantly as well as the corrosion current decreases from $5.5431 \mu \mathrm{A} / \mathrm{cm}^{2}$ to $1.0250 \mu \mathrm{A} / \mathrm{cm}^{2}$ and linear polarization value increase from 963 to $3130 \Omega \mathrm{cm}_{2}$. It is indicating the formation of safe layer on the metal surface ${ }^{(59)}$. The polarization curves of carbon steel immersed in well water with and without inhibitors are given in Figure 4 . The anodic slope value was increased from $116.23 \mathrm{mV} / \mathrm{dec}$ to $201.90 \mathrm{mV} / \mathrm{dec}$ and the cathodic slope value is increases from $110.88 \mathrm{mV} / \mathrm{dec}$ to $198.52 \mathrm{mV} / \mathrm{dec}$. Hence, anodic slope is greater than cathodic slope. Therefore, it is indicated that the inhibitor system behaves as a mixed type inhibitor ${ }^{(60)}$ but the anodic reaction is more controlled on the anodic side polarization than on the cathodic side polarization ${ }^{(61)}$.

Table 8. PolarizationParameters for PQ- $\mathrm{Zn}^{2+}$ System

\begin{tabular}{llllll}
\hline System & $\mathrm{E}_{\text {corr }}(\mathrm{mV}) \mathrm{vs} \mathrm{SCE}$ & $\mathrm{b}_{a}[\mathrm{mV} / \mathrm{dec}]$ & $\mathrm{b}_{c}(\mathrm{mV} / \mathrm{dec}]$ & $\mathrm{LPR}\left(\Omega \mathrm{cm}_{2}\right)$ & $\mathrm{I}_{\text {corr }} \mu \mathrm{A} / \mathrm{cm}^{2}$ \\
\hline Blank (well-water $)$ & -580 & 116.23 & 110.88 & 963 & 5.5431 \\
PQ- $\mathrm{Zn}^{2+}(500: 30 \mathrm{ppm})$ & -603 & 201.90 & 198.52 & 3130 & 1.0250 \\
\hline
\end{tabular}

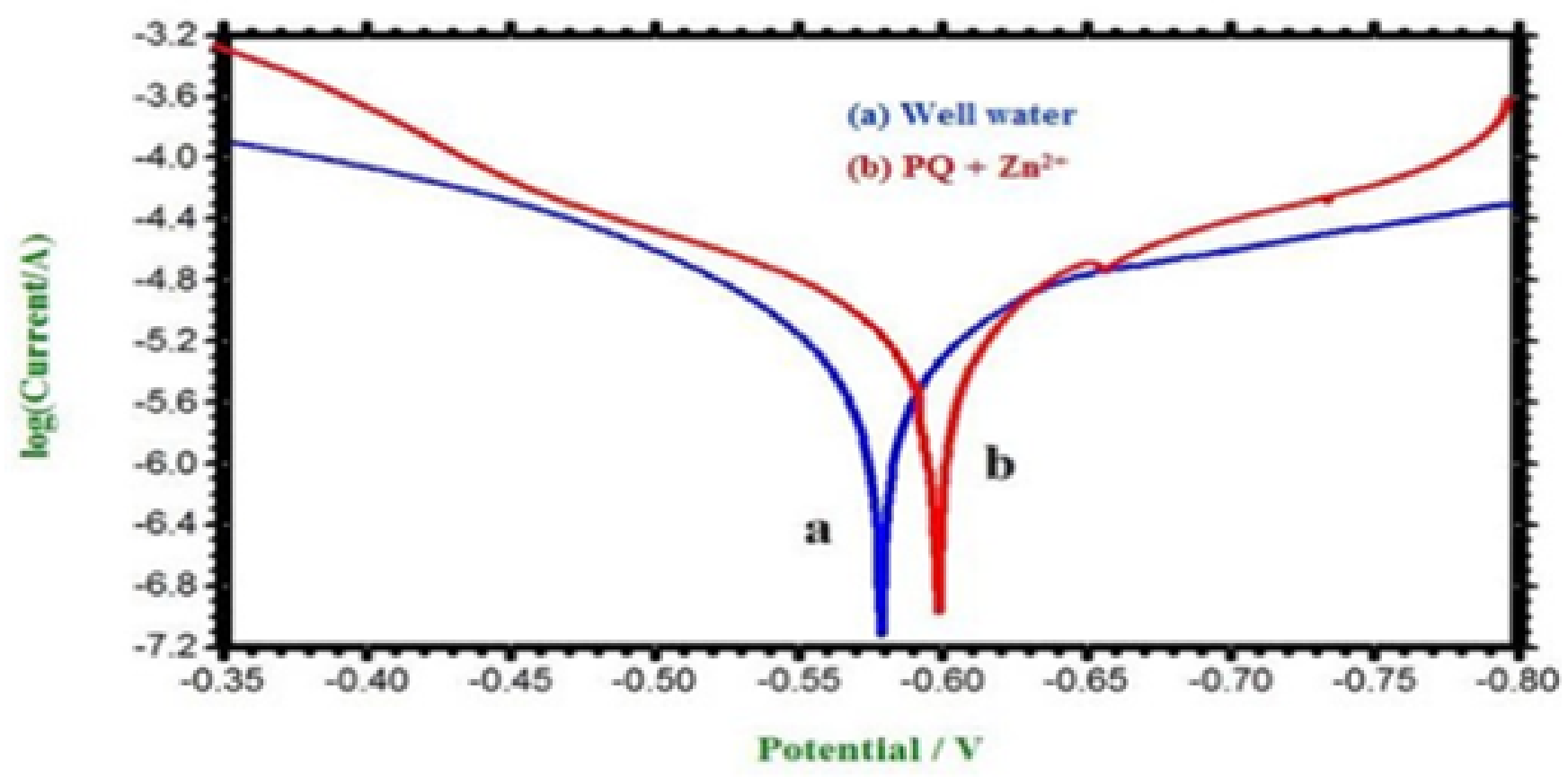

Fig 4. Tafel Curves for PQ- $\mathrm{Zn}_{2+}$ System onto carbon steel in well-water

\subsection{AC Impedance Spectra}

AC impedance spectra are used to accurately confirm the formation of the layer on carbon steel immersed in well-water containing 500ppm of PQ and $30 \mathrm{ppm}$ of $\mathrm{Zn}^{2+}$ as well as the calculated charge transfer resistance $\left(\mathrm{R}_{c t}\right)$ and the double layer capacitance $\mathrm{C}_{d l}$. The results are given in Table 9 
Table 9. AC ImpedanceParameters of well-water and PQ- $\mathrm{Zn}_{2+}$ System

\begin{tabular}{lll}
\hline System & $\mathrm{R}_{c t}\left(\Omega \mathbf{c m}_{2}\right)$ & $\mathrm{C}_{d l}\left(\mu \mathrm{F} / \mathrm{cm}^{2}\right)$ \\
\hline Blank(well-water) & 391 & 1.3137 \\
PQ- $Z \mathrm{n}_{2+}(500: 30 \mathrm{ppm})$ & 2530 & 0.0320 \\
\hline
\end{tabular}

The $\mathrm{R}_{c t}$ value is $391 \Omega \mathrm{cm}_{2}$ and $\mathrm{C}_{d l}$ value is $1.3137 \mu \mathrm{F} / \mathrm{cm}^{2}$, when carbon steel was immersed in well water without inhibitor concentration. When 500ppm of PQ and $30 \mathrm{ppm}$ of $\mathrm{Zn}^{2+}$ is added to the above system, the $\mathrm{R}_{c t}$ value has increased from 391 to $2530 \Omega \mathrm{cm}_{2}$ and the $\mathrm{C}_{d l}$ value is reduced from $1.3137 \mu \mathrm{F} / \mathrm{cm}^{2}$ to $0.0320 \mu \mathrm{F} / \mathrm{cm}^{2}$ this inhibitor system has better inhibition performance on the carbon steel in well water ${ }^{(62)}$. From the $\mathrm{R}_{c t}$ and $\mathrm{C}_{d l}$ values, this result indicates that the formation of a protective layer on the metal surface ${ }^{(63)}$. The AC impedance spectra of the carbon steel immersed in well-water containing 500 ppm of PQ and 30ppm of $\mathrm{Zn}^{2+}$ are shown in Figure 5.

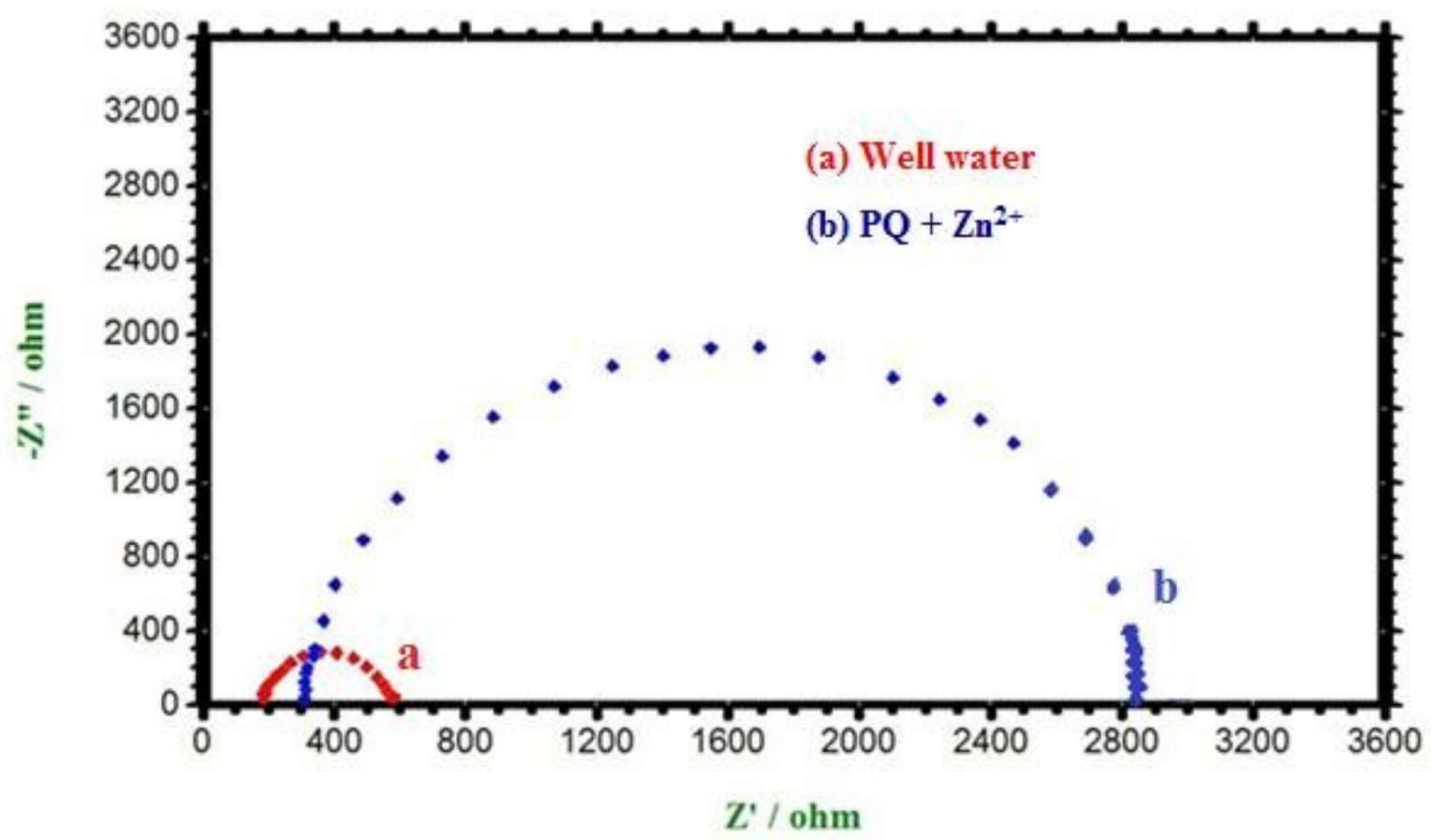

Fig 5. AC Impedance Spectrafor well-water (a) and PQ- $\mathrm{Zn}^{2+}$ System (b)

\subsection{Scanning Electron Microscopy technique}

Scanning electron microscope was used to understand the nature of the safe layer forming in carbon steel surface in the absence and presence of inhibitors and the extent of corrosion over carbon steel. The SEM images for different Magnification of carbon steel immersed in well water for one day with and without plant leaves extract are given in Figure $6(a, b, c)$. From image $6(a)$, it is indicating the smooth surface of the carbon steel and also the absence of any corrosion products onto the carbon steel surface. From image 6(b), this image indicates the roughness and the highly corroded area forming on carbon steel surface, when carbon steel immersed in well water. From image 6(c), this image shows the reduced corroded area on the carbon steel surface due to the formation of an insoluble complex on carbon steel surface when carbon steel immersed in well-water containing 500ppm of PQ and $30 \mathrm{ppm}$ of $\mathrm{Zn}^{2+}$. The damage of the steel surface has diminished in the presence of the inhibitor and rough, corroded steel surface displaces to much smooth ${ }^{(64)}$. This is due to the covering of metal surface with a protective layer ${ }^{(35)}$. The scanning electron microscope images for metal surface are investigated ${ }^{(51,65-68)}$. 


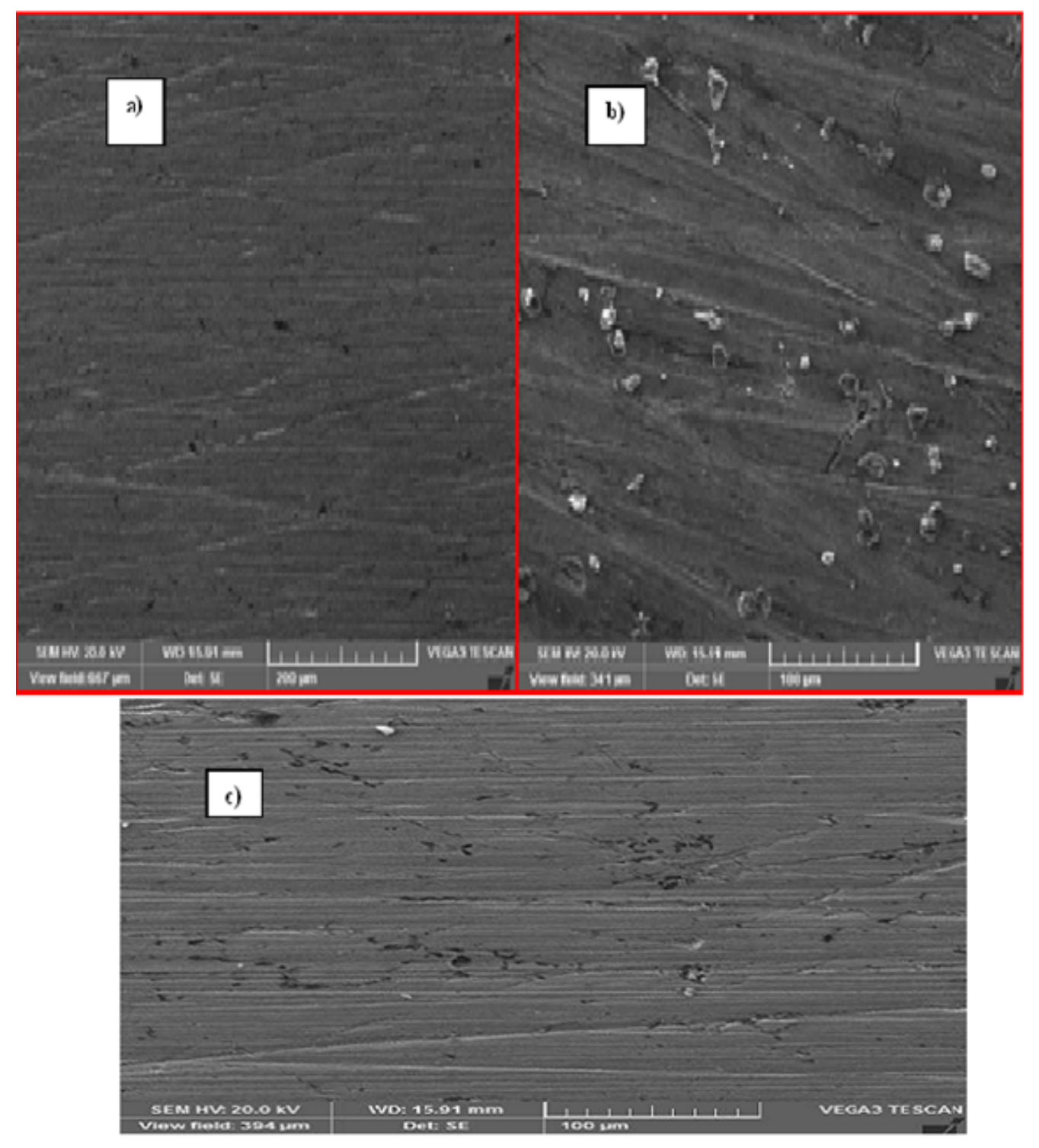

Fig 6. SEM images for Polished-Carbon steel (a), Blank (b), PQ-Za ${ }^{2+}$ system (c)

\subsection{Energy Dispersive X-Ray Study}

EDAX spectra are used to determine the composition of elements present on the metal surface ${ }^{(68)}$. The EDAX spectra result indicates that $\mathrm{N}, \mathrm{O}$, and $\mathrm{C}$ atoms of $\mathrm{PQ}$ extract and $\mathrm{Zn}^{2+}$ has coordinated with $\mathrm{Fe}^{2+}$ resulting in the formation of $\mathrm{Fe}^{2+}-\mathrm{PQ}$ complex on the anodic side of the metal surface as well as $\mathrm{Zn}(\mathrm{OH})_{2}$ is forming on the cathodic side of the metal surface. 

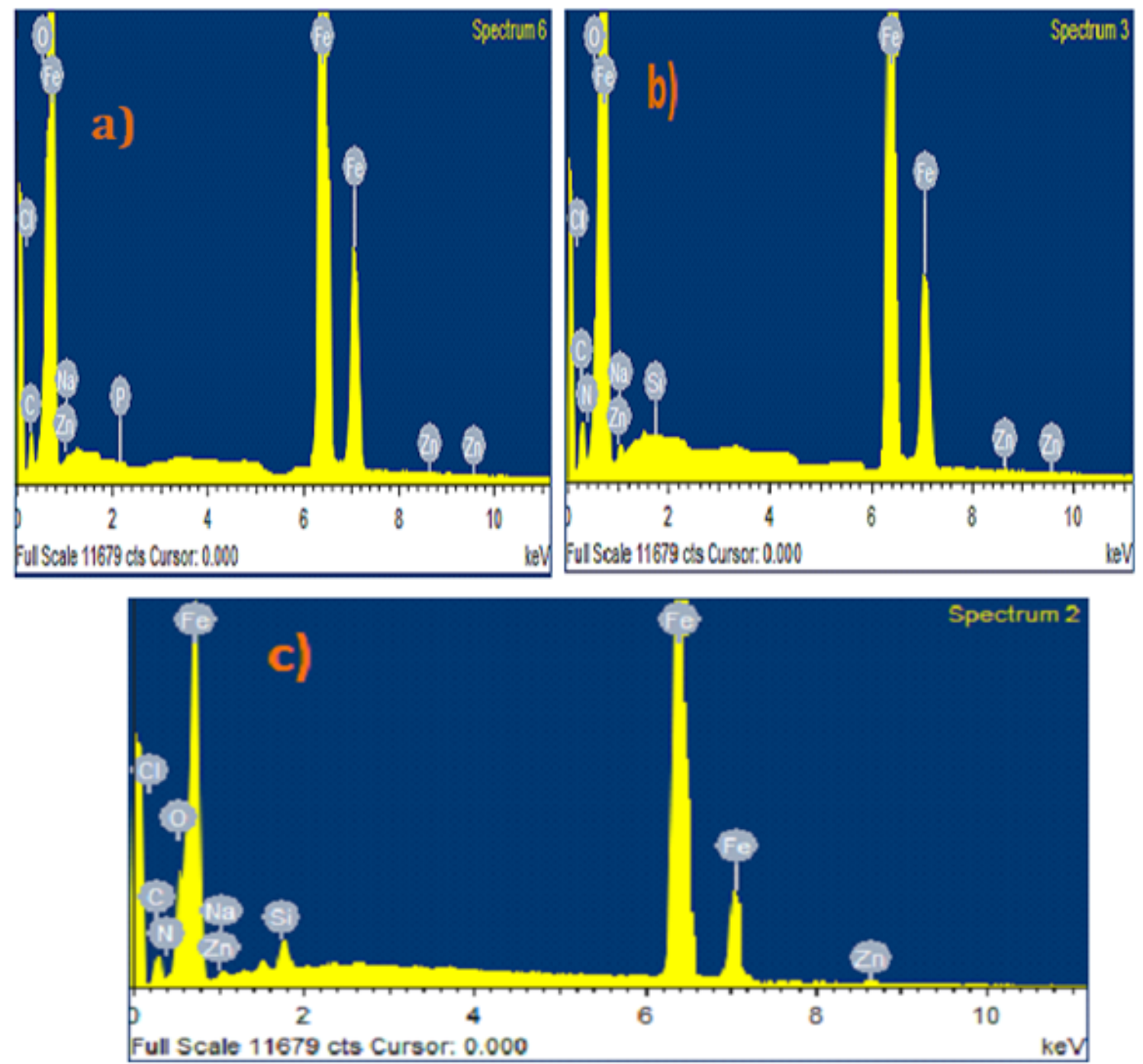

Fig 7. EDX Spectra of Polished carbon steel (a), Blank (b), PQ- $\mathrm{Zn}^{2+}$ system (c)

The EDAX spectrum of polished carbon steel is given in Figure 7 (a). This spectrum containing mainly Fe $\mathrm{C}$ and $\mathrm{O}$ signal. The EDAX spectrum of carbon steel immersed in well-water is shown in Figure 7(b) this spectrum shows the characteristic peaks of elements constituting the carbon steel specimen such as Fe, $\mathrm{C}, \mathrm{O}$ and $\mathrm{Cl}$ etc,. The EDAX spectrum of carbon immersed in well-water Containing 500ppm of PQ and 30ppm of $\mathrm{Zn}^{2+}$ is given in Figure 7(c). This spectrum indicating the additional elements present on the carbon steel surface $\mathrm{N}, \mathrm{O}, \mathrm{C}$, and $\mathrm{Zn}$ etc.,

\subsection{Atomic Force Microscopy techniques}

An Atomic force microscope was used to calculate the Root-mean Square Roughness $\left(\mathrm{R}_{r m s}\right)$, Average Roughness $\left(\mathrm{R}_{a}\right)$ and Maximum Peak-to-valley (P-V) height values, when carbon steel immersed in inhibited and uninhibited system. The results are given in Table 10. AFM is a useful technique to examine the surface morphology at nano-micro-scale to analysis the effect of the inhibitor on the generation and the progress of the corrosion at the metal/solution interface ${ }^{(68-70)}$.

The value of Root mean square roughness, Average Roughness and Maximum Peak-to-valley (P-V) height for polished carbon steel are $5.66 \mathrm{~nm}, 6.25 \mathrm{~nm}$, and $24.14 \mathrm{~nm}$ respectively. These values are indicating a more homogeneous surface. The 
Table 10. AFM parameters in absence and presence of PQ- $\mathrm{Zn}^{2+}$ system

\begin{tabular}{llll}
\hline sample & polished carbon steel & well-water (blank) & PQ- $\mathrm{Zn}_{2+}(500: 30 \mathrm{ppm})$ system \\
\hline $\left.\begin{array}{l}\text { Average Roughness }\left(\mathrm{R}_{a}\right)(\mathrm{nm}) \\
\begin{array}{l}\text { Root mean square roughness }\left(\mathrm{R}_{r m s}\right) \\
(\mathrm{nm})\end{array}\end{array}\right) 6.25$ & 1317.08 & 12.74 \\
$\begin{array}{l}\text { Maximum Peak-to-valley (P-V) height } \\
(\mathrm{nm})\end{array}$ & 24.14 & 1476.12 & 17.89 \\
\hline
\end{tabular}

Root mean square roughness, Average Roughness and Maximum Peak-to-valley (P-V) height values for carbon steel immersed in well-water are $13.17 \mathrm{~nm}, 1476.12 \mathrm{~nm}$, and $3791.00 \mathrm{~nm}$. these values suggest that the producing greater surface roughness compared with polished carbon steel surface, due to rate of corrosion is increases on carbon steel surface in well-water when carbon steel is immersed in well-water containing 500ppm of PQ and 30ppm of $\mathrm{Zn}^{2+}$, the Average Roughness value is reduced to $12.74 \mathrm{~nm}$ from $1317.08 \mathrm{~nm}$, Root mean square roughness $\left(\mathrm{R}_{r m s}\right)$ value was decreased to17.89nm from $1476.12 \mathrm{~nm}$ as well as Maximum Peak-to-valley (P-V) height value reduced to $102.31 \mathrm{~nm}$ from $3791.00 \mathrm{~nm}$, these parameters values are confirmed that the smoother surface appears over carbon steel specimen, due to the produces safe layer (nano-layer) ${ }^{(45)}$ of Fe ${ }^{2+}-\mathrm{PQ}$ extract complex and $\mathrm{Zn}(\mathrm{OH})_{2}$ on the carbon steel surface.
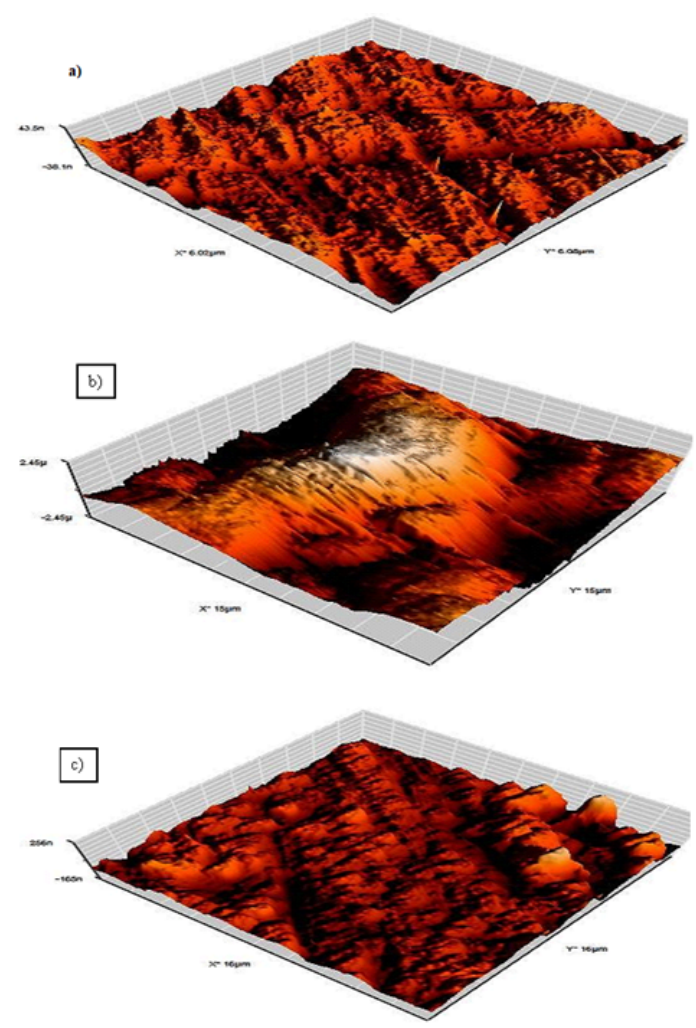

Fig 8. AFM 3D images for Polished carbon steel (a), Blank (b), and PQ- $\mathrm{Zn}^{2+}$ system (c)

From the above images, Figure 8 (a) for polished carbon steel surface is uncorroded carbon steel surface due to small roughness was obtained on polished carbon steel surface by atmospheric corrosion. Figure 8(b) for carbon steel is immersed in well-water. This image displays highly corroded on the metal surface with maximum roughness area. Figure 8(c) for carbon steel is immersed in well-water containing 500ppm of PQ extract and 30ppm of $\mathrm{Zn}^{2+}$. This AFM image appears smooth on the carbon steel surface due to formation of a protective film on the metal surface ${ }^{(64,71,72)}$. From the extract, this leads to the reduction of the corrosion of the carbon steel ${ }^{(1)}$. 


\subsection{Adsorption Isotherms Behaviour}

Adsorption isotherm models are used to investigate the possible adsorption mode of an ethanolic extract of PQ leaves by testing the experimental data obtained with four adsorption isotherm models ${ }^{(73)}$. The relationship between the surface coverage and the inhibitor concentration forms a basis to the study of the mechanism of adsorption isotherm ${ }^{(74)}$. All these isotherms are represented as follows ${ }^{(75)}$

$$
f(\theta, x) \exp (-2 a \theta)=K C
$$

Where, $\mathrm{f}(\theta, \mathrm{x})$ is the configurational factor, $\theta$ is the surface coverage, $\mathrm{C}$ is the concentration of the inhibitor, $\mathrm{X}$ is the molecular interaction parameter, and $\mathrm{K}$ is the equilibrium constant for the adsorption process.

The Langmuir adsorption isotherm is expressed as follows ${ }^{(35,76)}$.

$$
\frac{C}{\theta}=\frac{1}{K_{a d s}}+C
$$

EI-Awady adsorption isotherm is represented by using the following equation ${ }^{(77)}$

$$
\log \left(\frac{\theta}{1-\theta}\right)=\log K+y \log c
$$

Where, $\mathrm{K}_{a d s}$ is equilibrium constant of the adsorption process. It is related to $\mathrm{k}$ by

$$
K_{a d s=K^{1 / y}}
$$

Flory-Huggins adsorption isotherm is represented by ${ }^{(78)}$

$$
\log \left(\frac{\theta}{C}\right)=\log K+x \log (1-\theta)
$$

Where,

$\mathrm{X}$ is the size parameter,

Temkin adsorption isotherm is expressed by following equation ${ }^{(46)}$

$$
\theta=\frac{-2.303 \log K_{a d s}}{2 a}-\frac{2.303 \log C}{2 a}
$$

Where, $\mathrm{a}$ is the lateral interaction parameter. This isotherm graph is drawn by taking $\theta$ in the $\mathrm{y}$ axis and $\log \mathrm{c}$ in the $\mathrm{x}$ axis.

The data of regression co-efficient $\left(\mathrm{R}^{2}\right)$ were $0.997,0.928,0.992$, and 0.989 for Langmuir, El-Awady, Flory-Huggins, and Temkin models. From the regression co-efficient $\left(\mathrm{R}^{2}\right)$ values, the $\mathrm{R}^{2}$ values of four adsorption isotherm models were almost equal to unity ${ }^{(46)}$. However, the $\mathrm{R}^{2}$ value of Langmuir isotherm model was found to be high than another three adsorption isotherm models, this results show that the isotherm fits better at $303 \mathrm{~K}$ than the other higher temperatures and it has been reported by many researchers ${ }^{(79)}$. Therefore, the adsorption process of an ethanolic extract of PQ leaves follows the Langmuir isotherm model. The regression co-efficient $\left(\mathrm{R}^{2}\right)$ values are given in Table 11 . The $\mathrm{K}_{a d s}$ values are high at $303 \mathrm{k}$ for PQ- $\mathrm{Zn}^{2+}$ system and reduce with the increasing temperatures, indicating that the inhibitor is more strongly adsorbed on the metal surface of low temperature than at higher temperatures ${ }^{(80)}$. The $\mathrm{K}_{a d s}$ values are given in Table 2 . The various isotherm plots for the adsorption of ethanolic extract of PQ leaves on the carbon steel surface are shown in Figures 9, 10, 11 and 12.

Table 11. $\mathrm{R}^{2}$ values of various isotherms for $303 \mathrm{~K}$

\begin{tabular}{ll}
\hline various isotherm of combined inhibitor system & $\mathrm{R}^{2}$ \\
\hline Langmuir & 0.997 \\
Flory-Huggins & 0.928 \\
El-Awady & 0.992 \\
Temkin & 0.989 \\
\hline
\end{tabular}




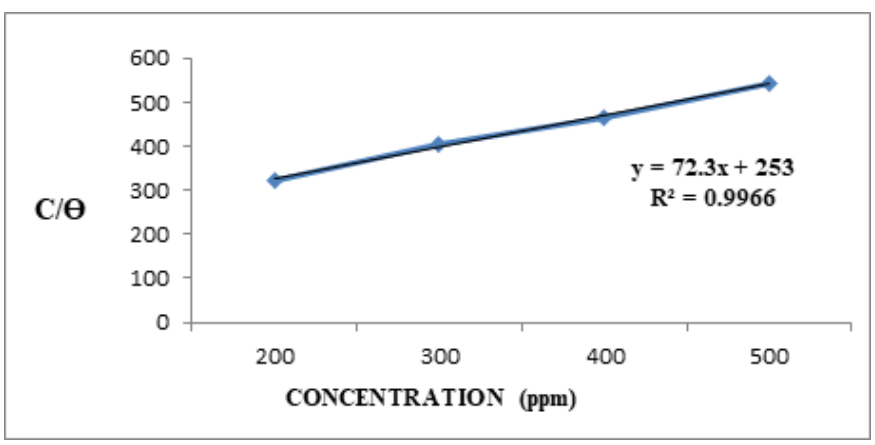

Fig 9. Langmuir adsorption isotherm of PQ inhibitor system at $303 \mathrm{~K}$

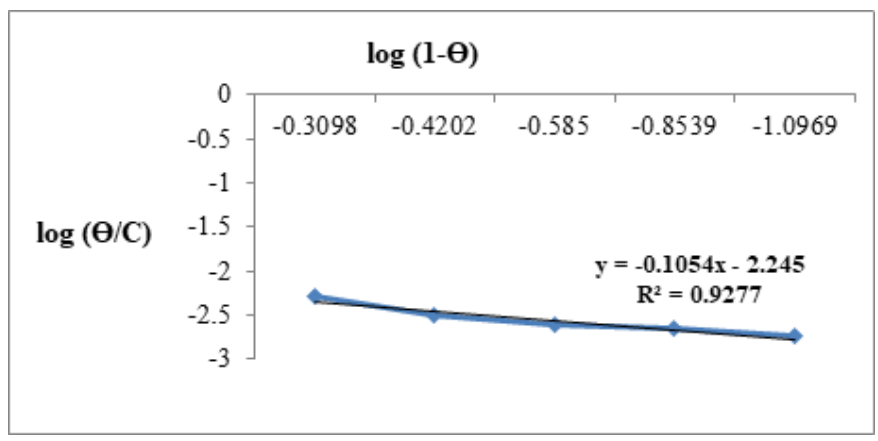

Fig 10. Flory - Huggins Adsorption Isotherm of PQ inhibitor system at $303 \mathrm{~K}$

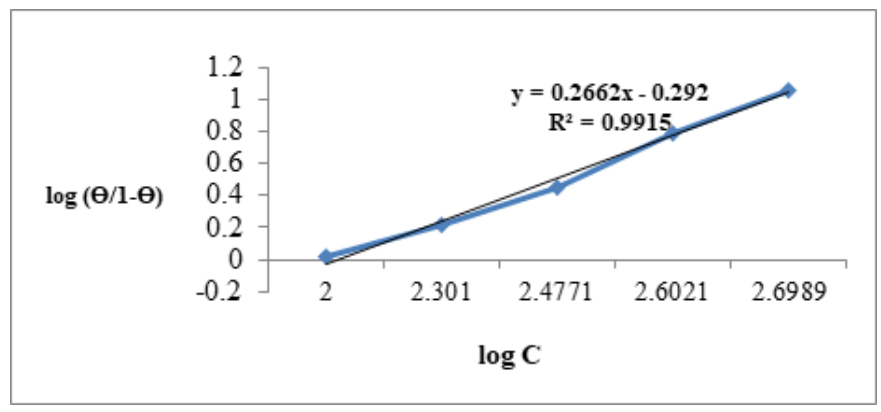

Fig 11. El-Awady Adsorption Isotherm of $P Q$ inhibitor system at $303 \mathrm{~K}$

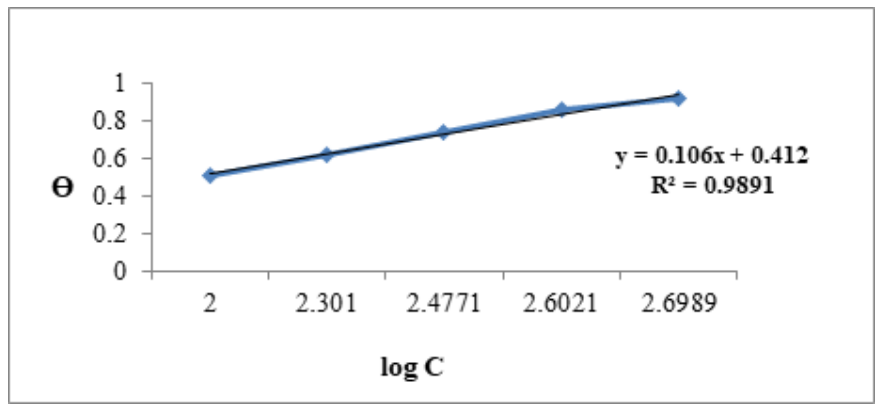

Fig 12. Temkin Adsorption Isotherm of PQ inhibitor system at $303 \mathrm{~K}$ 


\section{Conclusion}

The formulation consisting of 500ppm of $\mathrm{PQ}$ and $30 \mathrm{ppm}$ of $\mathrm{Zn}^{2+}$ system indicates $92 \%$ inhibition efficiency by using the weightloss method. The synergism parameters confirm the existence of a synergistic effect between PQ and $\mathrm{Zn}^{2+}$ ion. The F-Test confirms the effects of $10 \mathrm{ppm}$ and $20 \mathrm{ppm}$ of $\mathrm{Zn}^{2+}$ on inhibition efficiencies of different concentration of PQ is not statistically significant and 30ppm of $\mathrm{Zn}^{2+}$ on the inhibition efficiencies of different concentration of $\mathrm{PQ}$ is statistically significant. The Tafel slopes indicate that the PQ- $\mathrm{Zn}^{2+}$ system behaves as a mixed type inhibitor. AC impedance spectra confirm the formation of a protective layer on the carbon steel surface. The values of positive enthalpy changes show that the corrosion process occurs as endothermic reaction. The $\Delta \mathrm{G}_{a d s}$ values are negative in sign and range from -16.1 to $-18.0 \mathrm{KJ} / \mathrm{mol}$, the free energy of adsorption indicated that the corrosion inhibition take place by spontaneous physical adsorption of an ethanolic extract of PQ leaves on the carbon steel surface. The regression coefficient $\left(\mathrm{R}^{2}\right)$ values indicate that the adsorption of an ethanolic extract of Portulaca quadrifida leaves follows the Langmuir adsorption isotherm model. The Kads values indicate that the strongly adsorbed of an ethanolic extract of PQ leaves on the carbon steel surface. The microscopic studies including SEM, EDX, and AFM have indicated the presence of smooth surface in case of inhibited carbon steel when compared to the unhibited systems. The future work should be carried out in different metals with various corrosion mediums by using different methods, due to the ethanolic extract of PQ leaves is biodegradable, cheap, eco-friendly, and effective in well-water systems as a corrosion inhibition on the metal surface.

\section{References}

1) Ali AE, Badr GE, El-Aziz SFA. Citrus sinensis extract as a Green inhibitor for the corrosion of carbon steel in sulphuric acid solution. Biointerface Research in Applied Chemistry. 2021;11(6):14007-14020. Available from: https://doi.org/10.33263/BRIAC116.1400714020.

2) Zhang R, Castel A, François R. Concrete cover cracking with reinforcement corrosion of RC beam during chloride-induced corrosion process. Cement and Concrete Research. 2010;40(3):415-425. Available from: https://dx.doi.org/10.1016/j.cemconres.2009.09.026.

3) Müller B. Corrosion inhibition of aluminium and zinc pigments by saccharides. Corrosion Science. 2002;44(7):1583-1591. Available from: https: //doi.org/10.1016/S0010-938X(01)00170-6.

4) El-Hosary AA, Saleh RM, Din ASE. Corrosion inhibition by naturally occurring substances-I. The effect of Hibiscus subdariffa (karkade) extract on the dissolution of Al and Zn. Corrosion Science. 1972;12(12):897-904. Available from: https://doi.org/10.1016/S0010-938X(72)80098-2.

5) El-Etre AY. Inhibition of aluminum corrosion using Opuntia extract. Corrosion Science. 2003;45(11):2485-2495. Available from: https://doi.org/10.1016/ S0010-938X(03)00066-0.

6) El-etre AY. Natural honey as corrosion inhibitor for metals and alloys. i. copper in neutral aqueous solution. Corrosion Science. 1998;40(11):1845-1850. Available from: https://doi.org/10.1016/S0010-938X(98)00082-1.

7) El-Etre AY, Abdallah M. Natural honey as corrosion inhibitor for metals and alloys. II. C-steel in high saline water. Corrosion Science. 2000;42(4):731-738. Available from: https://dx.doi.org/10.1016/s0010-938x(99)00106-7.

8) El-Etre AY. Khillah extract as inhibitor for acid corrosion of SX 316 steel. Applied Surface Science. 2006;252(24):8521-8525. Available from: https://dx.doi.org/10.1016/j.apsusc.2005.11.066.

9) El-Etre AY. Inhibition of acid corrosion of aluminum using vanillin. Corrosion Science. 2001;43(6):1031-1039. Available from: https://dx.doi.org/10.1016/ s0010-938x(00)00127- $x$

10) Bouyanzer A, Hammouti BA. Study of anti-corrosive effects of Artemisia oil on steel. Pigment \& Resin Technology. 2004;33(5):287-292. Available from: https://doi.org/10.1108/03699420410560489.

11) Oguzie EE. Inhibition of acid corrosion of mild steel byTelfaria occidentalisextract. Pigment \& Resin Technology. 2005;34(6):321-326. Available from: https://dx.doi.org/10.1108/03699420510630336.

12) Sethuraman MG, Raja PB. Corrosion inhibition of mild steel by Datura metel in acidic medium. Pigment \& Resin Technology. 2005;34(6):327-331. Available from: https://dx.doi.org/10.1108/03699420510630345.

13) Donnelly B, Downie TC, Grzeskowiak R, Hamburg HR, Short D. The effect of electronic delocalization in organic groups R in substituted thiocarbamoyl RCSNH2 and related compounds on inhibition efficiency. Corrosion Science. 1978;18(2):109-116. Available from: https://dx.doi.org/10.1016/s0010938x(78)80081-x.

14) Khaled K. Electrochemical investigation and modelling of corrosion inhibition of aluminium in molar nitric acid using some sulphur-containing amines. Corrosion Science. 2010;52(9):2905-2916. Available from: https://doi.org/10.1016/j.corsci.2010.05.001.

15) Zhang Q, Gao Z, Xu F, Zou X. Adsorption and corrosion inhibitive properties of gemini surfactants in the series of hexanediyl-1,6-bis-(diethyl alkyl ammonium bromide) on aluminium in hydrochloric acid solution. Colloids and Surfaces A: Physicochemical and Engineering Aspects. 2011;380(1-3):191200. Available from: https://dx.doi.org/10.1016/j.colsurfa.2011.02.035.

16) Şafak S, Duran B, Yurt A, Türkoğlu G. Schiff bases as corrosion inhibitor for aluminium in HCl solution. Corrosion Science. 2012;54:251-259. Available from: https://dx.doi.org/10.1016/j.corsci.2011.09.026.

17) Yurt A, Aykın O. Dipherdic Schiff bases as corrosion inhibitors for aluminium in $0.1 \mathrm{M} \mathrm{HCl}$ : potentiodynamic polarisation and EQCM investigations. Corrosion Science. 2011;53(11):3725-3732. Available from: https://doi.org/10.1016/j.corsci.2011.07.018.

18) Patel AS, Panchal VA, Mudaliar GV, Shah NK. Impedance spectroscopic study of corrosion inhibition of Al-Pure by organic Schiff base in hydrochloric acid. Journal of Saudi Chemical Society. 2013;17(1):53-59. Available from: https://dx.doi.org/10.1016/j.jscs.2011.06.003.

19) Musa AY, Kadhum AAH, Mohamad AB, Takriff MS, Chee EP. Inhibition of aluminum corrosion by phthalazinone and synergistic effect of halide ion in 1.0M HCl. Current Applied Physics. 2012;12(1):325-330. Available from: https://dx.doi.org/10.1016/j.cap.2011.07.001.

20) Lashgari M, Malek AM. Fundamental studies of aluminum corrosion in acidic and basic environments: Theoretical predictions and experimental observations. Electrochimica Acta. 2010;55(18):5253-5257. Available from: https://dx.doi.org/10.1016/j.electacta.2010.04.054. 
21) Khaled KF, Al-Qahtani MM. The inhibitive effect of some tetrazole derivatives towards Al corrosion in acid solution: Chemical, electrochemical and theoretical studies. Materials Chemistry and Physics. 2009;113(1):150-158. Available from: https://dx.doi.org/10.1016/j.matchemphys.2008.07.060.

22) Fouda AS, Al-Sarawy AA, Ahmed FSH, El-Abbasy H. Corrosion inhibition of aluminium 6063 using some pharmaceutical compounds. Corrosion Science. 2009;51(3):485-492. Available from: https://doi.org/10.1016/j.corsci.2008.10.012.

23) Abdallah M. Antibacterial drugs as corrosion inhibitors for corrosion of aluminium in hydrochloric solution. Corrosion Science. 2004;46(8):1981-1996. Available from: https://dx.doi.org/10.1016/j.corsci.2003.09.031.

24) Rani BEA, Basu BBJ. Green Inhibitors for Corrosion Protection of Metals and Alloys: An Overview. International Journal of Corrosion. 2012;2012:1-15. Available from: https://dx.doi.org/10.1155/2012/380217.

25) Nazari MH, Shihab MS, Havens EA, Shi X. Mechanism of corrosion protection in chloride solution by an apple-based green inhibitor: experimental and theoretical studies. Journal of infrastructure preservation and Resilience. 2020;1:1-19. Available from: https://doi.org/10.1186/s43065-020-00007-w.

26) Okafor PC, Ebenso EE, El-Etre AY, Quraishi MA. Green Approaches to Corrosion Mitigation. International Journal of Corrosion. 2012;2012(2):1-2. Available from: https://dx.doi.org/10.1155/2012/908290.

27) Abdel-Gaber AM, Abd-El-Nabey BA, Sidahmed IM, El-Zayady AM, Saadawy M. Inhibitive action of some plant extracts on the corrosion of steel in acidic media. Corrosion Science. 2006;48(9):2765-2779. Available from: https://dx.doi.org/10.1016/j.corsci.2005.09.017.

28) Oguzie EE. Evaluation of the inhibitive effect of some plant extracts on the acid corrosion of mild steel. Corrosion Science. 2008;50(11):2993-2998. Available from: https://dx.doi.org/10.1016/j.corsci.2008.08.004.

29) Mo S, Luo HQ, Li NB. Plant extracts as green corrosion inhibitors for steel in sulphuric acid. Chemical Papers. 2016;70(9):1131-1143. Available from: https://doi.org/10.1515/chempap-2016-0055.

30) Bouklah M, Hammouti B, Benkaddour M, Benhadda T. Thiophene derivatives as effective inhibitors for the corrosion of steel in $0.5 \mathrm{~m} \mathrm{H} 2 \mathrm{SO}$. Journal of Applied Electrochemistry. 2005;35(11):1095-1101. Available from: https://dx.doi.org/10.1007/s10800-005-9004-z.

31) Fouda AS, Al-Sarawy AA, El-Katori EE. Pyrazolone derivatives as corrosion inhibitors for C-steel in hydrochloric acid solution. Desalination. 2006;201(13):1-13. Available from: https://dx.doi.org/10.1016/j.desal.2006.03.519.

32) Aralu CC, Chukwuemeka-Okorie HO, Akpomie KG. Inhibition and adsorption potentials of mild steel corrosion using methanol extract of Gongronema latifoliuim. Applied Water Science. 2021;11(2):22-23. Available from: https://dx.doi.org/10.1007/s13201-020-01351-8.

33) Rajendran S, Thangavelu C, Angamuthu, Jayakumar S. Inhibition of corrosion of aluminium in alkaline medium by glutaric acid in conjunction with zinc sulphate and diethylene triamine (Methylene phosphonic acid). Archives of Applied Science Research. 2013;5(1):202-212.

34) Doner A, Solmaz R, Ozcan M, Kardas G. Experimental and theoretical studies of thiazoles as corrosion inhibitors for mild steel in sulphuric acid solution. Corrosion Science. 2011;53:2902-2913.

35) Hynes NRJ, Selvaraj RM, Mohamed T, Mukesh AM, Olfa K, Nikolova MP. Aerva lanata flowers extract as green corrosion inhibitor of low-carbon steel in HCl solution: an in vitro study. Chemical Papers. 2021;75(3):1165-1174. Available from: https://dx.doi.org/10.1007/s11696-020-01361-5.

36) Haldhar R, Prasad D, Kamboj D, Kaya S, Dagdag O, Guo L. Corrosion inhibition, surface adsorption and computational studies of Momordica charantia extract: a sustainable and green approach. SN Applied Sciences. 2021;3(1):1-13. Available from: https://dx.doi.org/10.1007/s42452-020-04079-x.

37) Parveen M, Mobin M, Zehra S. Evaluation of l-tyrosine mixed with sodium dodecyl sulphate or cetyl pyridinium chloride as a corrosion inhibitor for mild steel in 1 M HCl: experimental and theoretical studies. RSC Advances. 2016;6(66):61235-61248. Available from: https://dx.doi.org/10.1039/c6ra10010d.

38) Florez-Frias EA, Barba V, Lopez-Sesenes R, Landeros-Martínez LL, los Ríos JPFD, Casales M, et al. Use of a Metallic Complex Derived from Curcuma Longa as Green Corrosion Inhibitor for Carbon Steel in Sulfuric Acid. International Journal of Corrosion. 2021;2021:1-13. Available from: https: //dx.doi.org/10.1155/2021/6695299.

39) Selvaraj SK. Eco-friendly extract of Portulaca quadrifida as corrosion inhibitor for carbon steel in 1M Hydrochloric acid solution. World Journal of Pharmaceutical research. 2018;7(06):1047-1062.

40) Kalaivani P, Arasu PT, Rajendran S. Inhibition performance on the surface of aluminium in alkaline medium. International Journal ChemTech Research. 2013;5(4):1714-1723.

41) Kanimozhi AS, Rajendran S. Inhibitive properties of sodium tungstate -Zn2+- system and its synergism with HEDP. International Journal of Electrochemical Science. 2009;4(3):353-368. Available from: http://www.electrochemsci.org/papers/vol4/4030353.pdf.

42) Umoren SA, Ebenso EE. The synergistic effect of polyacrylamide and iodide ions on the corrosion inhibition of mild steel in $\mathrm{H} 2 \mathrm{SO}$. Materials Chemistry and Physics. 2007;106(2-3):387-393. Available from: https://dx.doi.org/10.1016/j.matchemphys.2007.06.018.

43) Amin MA, Khaled KF, Fadl-Allah SA. Testing validity of the Tafel extrapolation method for monitoring corrosion of cold rolled steel in HCl solutions Experimental and theoretical studies. Corrosion Science. 2010;52(1):140-151. Available from: https://dx.doi.org/10.1016/j.corsci.2009.08.055.

44) Amin MA, Ibrahim MM. Corrosion and corrosion control of mild steel in concentrated $\mathrm{H} 2 \mathrm{SO} 4$ solutions by a newly synthesized glycine derivative. Corrosion Science. 2011;53(3):873-885. Available from: https://dx.doi.org/10.1016/j.corsci.2010.10.022.

45) Begum AAS, Vahith RMA, Kotra V, Shaik MR, Abdelgawad A, Awwad EM, et al. Spilanthes acmella Leaves Extract for Corrosion Inhibition in Acid Medium. Coatings. 2021;11(1):106-106. Available from: https://dx.doi.org/10.3390/coatings11010106.

46) Prabha KL, Rajam S, Subramania A. The effect of aqueous extract of Adathoda vasica leaves on corrosion inhibition of aluminium in alkaline solution. Journal of chemical and pharmaceutical Research. 2012;4(1):337-347. Available from: https://www.jocpr.com/articles/the- effect-of-aqueous-extract-ofadathoda-vasica-leaves-on-corrosion-inhibitionof-aluminium-in-alkaline-solution.pdf.

47) Vennila T, Muneeswaran T, Manjula M, Stalin B, Vairamuthu J. Synergism between sodium molybdate and binary inhibitor (BHI + Zn2+) on corrosion inhibition of mild steel in aqueous medium containing $60 \mathrm{ppm} \mathrm{Cl}-$ ion. Materials Research Express. 2019;6(11):1165g6-1165g6. Available from: https://dx.doi.org/10.1088/2053-1591/ab5233.

48) Rajendran S, Reenkala SM, Anthony N, Ramaraj R. Synergistic corrosion inhibition by the sodium dodecylsulphate-Zn2+ system. Corrosion Science. 2002;44(10):2243-2252. Available from: https://dx.doi.org/10.1016/s0010-938x(02)00052-5.

49) Satapathy AK, Gunasekaran G, Sahoo SC, Amit K, Rodrigues PV. Corrosion inhibition by Justicia gendarussa plant extract in hydrochloric acid solution. Corrosion Science. 2009;51(12):2848-2856. Available from: https://dx.doi.org/10.1016/j.corsci.2009.08.016.

50) Epshiba R, Regis APP, Clarebel RB, Mary SP, Alphonsa AP, Alphonsa JK. Influence of Aloe vera extract on corrosion inhibition of mild steel in well water. Re TeLL. 2015;15:1-11. Available from: https://www.sjctni.edu/retell/content/2015_\%20R.\%20Epshiba_11-12-2019_3.pdf.

51) Raja AS, Sathiyabama J, Prathiba V. Corrosion inhibition of vitex negundo extract as a green corrosion inhibitor for carbon steel in well-water. International Journal of Chemical Studies. 2014;2(1):31-37. Available from: https://www.chemijournal.com/archives/2014/vol2issue1/PartA/29.1.pdf.

52) Li X, Deng S, Fu H, Mu G. Synergism between rare earth cerium(IV) ion and vanillin on the corrosion of cold rolled steel in $1.0 \mathrm{M} \mathrm{HCl} \mathrm{solution.} \mathrm{Corrosion}$ Science. 2008;50(12):3599-3609. Available from: https://dx.doi.org/10.1016/j.corsci.2008.09.029. 
53) Umoren SA, Obot IB, Ebenso EE, Okafor PC. Eco-friendly Inhibitors from Naturally Occurring Exudate Gums for Aluminium Corrosion Inhibition in Acidic Medium. Portugaliae Electrochimica Acta. 2007;26(3):267-282. Available from: https://dx.doi.org/10.4152/pea.200803267.

54) Raja AS, Sathiyabama J, Prathiba V. Corrosion inhibition of vitex negundo extract as a green corrosion inhibitor for carbon steel in well-water. International Journal of Chemical Studies. 2014;2(1):31-37. Available from: https://www.chemijournal.com/archives/2014/vol2issue1/PartA/29.1.pdf.

55) Manivannan M, Rajendran S. Investigation of inhibitive action of urea $\mathrm{Zn} 2+$ system in the corrosion control of carbon steel in sea water. International Journal of Engineering Science Technology. 2011;3(11):8048-8060.

56) Sheeba RS, Raja AS, Sathiyabama J, Prathipa V. Green approach to corrosion inhibition of carbon steel in well water by the extract of Polyalthia longifolia. Journal of applicable chemistry. 2014;3(5):2055-2065. Available from: http://www.joac.info/ContentPaper/2014/4-22.pdf.

57) Sangeetha M, Rajendran S, Sathiyabama J, Krishnaveni A, Shanthy P, Manimaran N, et al. Corrosion Inhibition by an Aqueous Extract of Phyllanthus Amarus. Portugaliae Electrochimica Acta. 2011;29(6):429-444. Available from: https://dx.doi.org/10.4152/pea.201106429.

58) Iroba NB, Maduelosi NJ. Corrosion inhibitive action and adsorption behaviour of Justicia secunda leaves extract as an Eco-friendly inhibitor for aluminium in acidic media. Biointerface Research in Applied Chemistry. 2021;11(5):13019-13030.

59) Sharmila A, Prema AA, Sahayaraj PA. Influence of Murraya koenigii (curry leaves) extract on the corrosion inhibition of carbon steel in HCL solution. Rasayan Journal of Chemistry. 2010;3(1):74-81. Available from: https://rasayanjournal.co.in/vol-3/issue-1/12.pdf.

60) Sangeetha M, Rajendran S, Sathiyabama J, Prabhakar P. Influence of Murraya koenigii (curry leaves) extract on the corrosion inhibition of carbon steel in $\mathrm{HCl}$ solution. Journal of Natural Product and Plant Resources. 2012;2(5):601-610.

61) A SF, A HB. Aqueous extract of propolis as corrosion inhibitor for carbon steel in aqueous solutions. African Journal of Pure and Applied Chemistry. 2013;7(10):350-359. Available from: https://dx.doi.org/10.5897/ajpac2013.0524.

62) Rose AL, Rani FRS, Regis APP, Rose CM. Corrosion behaviour of carbon steel in river water in the presence of lactic acid-Zn2+ system. International Journal ChemTech Research. 2012;4(1):157-164. Available from: http://www.sphinxsai.com/2012/chem/CHEM/CT=27(157-164)JM12.pdf.

63) Jayashree A, Selvarani FR, Sahayaraj JW, Amalraj AJ, Rajendran S. Malonic Acid as Transporter of Zn2+ Towards Carbon Steel Surface. Portugaliae Electrochimica Acta. 2009;27(1):23-32. Available from: https://dx.doi.org/10.4152/pea.200901023.

64) Fouda AS, El-Desoky HS, Abdel-Galeil MA, Mansour D. Niclosamide and dichlorphenamide: new and effective corrosion inhibitors for carbon steel in $1 \mathrm{M} \mathrm{HCl}$ solution. SN Applied Sciences. 2021;3(3):1-20. Available from: https://dx.doi.org/10.1007/s42452-021-04155-w.

65) Raja SS, Rajendran S, Sathiyabama P. Inhibition of corrosion of carbon steel in well water by DL-Phenylalanine - Zn2+ system. Journal of Chemistry. 2013;p. 1-8. Available from: https://doi.org/10.1155/2013/720965.

66) Sivakumar S, Raja AS, Sathiyabama J, Prathipa V. Spectroscopic methods used for analysing protective film formed by L-Histidine on carbon steel. International Journal of Pharmaceutical Drug Analysis. 2014;2(7):601-611. Available from: https://www.ijpda.com/index.php/journal/article/view/86.

67) Liao QQ, Yue ZW, Yang D, Wang ZH, Li YJ. Inhibition of copper corrosion in sodium chloride solution by the self-assembled monolayer of sodium diethlydithio carbamate. Corrosion Science. 2011;53(5):1999-2005. Available from: https://doi.org/10.1016/j.corsci.2011.02.023.

68) Umoren SA, Li Y, Wang FH. Electrochemical study of corrosion inhibition and adsorption behaviour for pure iron by polyacrylamide in $\mathrm{H} 2 \mathrm{SO} 4$ : Synergistic effect of iodide ions. Corrosion Science. 2010;52(5):1777-1786. Available from: https://dx.doi.org/10.1016/j.corsci.2010.01.026.

69) Solmaz R, Kardaş G, Çulha M, Yazıcı B, Erbil M. Investigation of adsorption and inhibitive effect of 2-mercaptothiazoline on corrosion of mild steel in hydrochloric acid media. Electrochimica Acta. 2008;53(20):5941-5952. Available from: https://dx.doi.org/10.1016/j.electacta.2008.03.055.

70) Wang B, Du M, Zhang J, Gao CJ. Electrochemical study of corrosion inhibition of Q235 steel by imidazoline derivative against CO2 Corrosion. Corrosion Science. 2011;53(1):353-361. Available from: https://doi.org/10.1016/j.corsci.2010.09.042.

71) Nasibi M, Mohammady M, Ghasemi E, Ashrafi A, Zaarei D, Rashed G. Corrosion inhibition of mild steel by Nettle (Urtica dioicaL.) extract: polarization, EIS, AFM, SEM and EDS studies. Journal of Adhesion Science and Technology. 2013;27(17):1873-1885. Available from: https://dx.doi.org/10.1080/ 01694243.2013.764144. doi:10.1080/.

72) Yuce AO, Kardas G. Adsorption and inhibition effect of 2-thiohydantoin on mild steel corrosion in 0.1M HCl. Corrosion Science. 2012;58:86-94. Available from: https://doi.org/10.1016/j.corsci.2012.01.013.

73) Nnanna LA, Nwadiuko OC, Ekekwe ND, Ukpabi CF, Udensi SC, Okeoma KB. Adsorption and Inhibitive Properties of Leaf Extract of Newbouldia leavis as a Green Inhibitor for Aluminium Alloy in H2SO4. American Journal of Materials Science. 2012;1(2):143-148. Available from: https://dx.doi.org/10. 5923/j.materials.20110102.24.

74) Nwosu O, Osarolube E. Corrosion Inhibition of Aluminium Alloy in $0.75 \mathrm{M} \mathrm{KOH}$ Alkaline Solution Using Xylopia aethiopica Seed Extract. Physical Science International Journal. 2014;4(9):1235-1243. Available from: https://dx.doi.org/10.9734/psij/2014/9928.

75) Ogunleye OO, Arinkoola AO, Eletta OA, Agbede OO, Osho YA, Morakinyo AF, et al. Green corrosion inhibition and adsorption characteristics of Luffa cylindrica leaf extract on mild steel in hydrochloric acid environment. Heliyon. 2020;6(1):1-12. Available from: https://doi.org/10.1016/j.heliyon.2020. e03205.

76) Bilgic S, Caliskan N. An investigation of some Schiff bases as corrosion inhibitors for Austenite chromium-nickel steel in H2SO4. Journal of Applied Electrochemistry. 2001;31(1):79-83. Available from: http://dx.doi.org/10.1023/A:1004182329826.

77) Adejo SO, Yiase SG, Ahile UJ, Tyohemba TG, Gbertyo JA. Inhibitory effect and adsorption parameters of extract leaves of Portulaca oleracea of corrosion of aluminium in $\mathrm{H} 2 \mathrm{SO} 4$ solution. Archives of Applied Science Research. 2013;5(1):25-32.

78) Al-Fakih AM, Aziz M, Sirat HM. Turmeric and ginger as green inhibitors of mild steel corrosion in acidic medium. Journal of Materials and Environmental Science. 2015;6(5):1480-1487. Available from: https://www.jmaterenvironsci.com/Document/vol6/vol6_N5/174-JMES-1396-2015-Al-Fakih.pdf.

79) Refaey SAM, Taha F, El-Malak AMA. Inhibition of stainless steel pitting corrosion in acidic medium by 2 -mercaptobenzoxazole. Applied Surface Science. 2004;236(1-4):175-185. Available from: https://dx.doi.org/10.1016/j.apsusc.2004.04.016.

80) Ebenso EE, Obot IB, Murulana LC. Quinoline and its derivatives as effective corrosion inhibitors for mild steel in acidic medium. International Journal of Electrochemical science. 2010;5(11):1574-1586. 